\title{
PEMASARAN PRODUK BAKERY ROTI DI PONDOK PESANTREN AL- MASHDUQIAH PATOKAN KRAKSAAN
}

\author{
Tri Nadhirotur Roifah \\ Email: trinadhir@gmail.com \\ Universitas Islam Zainul Hasan Genggong \\ Dewi Pramita \\ Universitas Islam Zainul Genggong Kraksaan Probolinggo
}

\begin{abstract}
Competition in economic activities is often used to find out how marketing strategies are formed. To establish a marketing strategy by a company, something product can be offered to the market to get attention to be bought, used, or consumed, so that it can meet the wants and needs. In the marketing mix strategy, the first step to take is a product strategy. This is very important because what will be sold is the product and consumers will get to know the company through the products that will be offered. Whereas marketing is marketing, marketing strategy is the design, implementation, and control of plans to influence exchange in order to achieve organizational goals. Strategy is an organizational tool used to achieve its objectives, and therefore, marketing strategy is needed in achieving success.

This research is a type of field research (filed research), which is a study by conducting observations about a phenomenon in a scientific situation. While in data collection using, observation, interview, and documentation.

The results of this study explain that the Home Industry of Bakery Bread Products use a face to face strategy, a cooperation strategy. And marketing mix which includes product strategy, price, place, promotion. After exposing the marketing of Bakery Bread products, it is expected to activate the stages of product marketing in all places by looking at the conditions of strengths and weaknesses and environmental changes, so that it can find out whether marketing is applied right on target or not. And further enhance the development of the ability of employees to convince the public to trust the industry that has been created by the Al-Mashduqiah Islamic Boarding School, so that the product becomes better and is also well-known among the outside community.
\end{abstract}

Keywords: Marketing, Products, Bakery Bread 


\section{Pendahuluan}

Di dalam suatu perusahaan mengembangkan strategi untuk mengatasi ancaman internal maupun eksternal merebut peluang yang ada. Tujuan utama pelaksanaan strategi adalah perusahaan dapat melibatkan secara obyektif kondisikondisi internal dan eksternal. Jadi perencanaan strategi pemasaran penting untuk memperoleh keunggulan bersaing dan memiliki produk yang sesuai dengan keinginan konsumen dengan dukungan sumberdaya pemasaran. Maka dengan adanya strategi pemasaran ini Pondok Peasantren Al-mashduqiah meluncurkan produk yang bernama Bakery Roti.

Strategi pemasaran juga dapat diartikan sebagai tujuan dan juga sasaran, sehingga dengan adanya strategi pemasaran tersebut perusahaan dapat memberikan arahan kepada setiap pemasaran pada waktu ke waktu, maka dari itu pondok Pesantren Al-mashduqiah menciptakan sebuah produk yang berkualitas dalam kegiatan pemasaran dan dalam industri bisnis ini harus direncanakan sesuai strategi yang optimal.

strategi pemasaran adalah sebuah rencana yang menyeluruh, yang dapat memberikan panduan pada setiap kegiatan yang akan dijalankan untuk mencapai pada kesuksesan dalam sebuah perusahaan. kebijakan dan aturan yang ada didalam perusahaan dapat memberikan arahan kepada semua usaha-usaha pemasaran perusahaan dari waktu ke waktu, pada masing-masing tanggapan perusahaan dalam menghadapi lingkungan dan keadaan persaingan yang selalu berubah. Oleh karena itu, strategi pemasaran mempunyai peranan yang sangat penting untuk keberhasilan usaha perusahaan. Akan tetapi dengan adanya persaingan yang begitu ketat Pondok Pesantren Al-mashduqiah masih belum berani untuk membuat sebuah toko.

Pemasaran adalah sistem keseluruhan usaha yang merencanakan, atau menentukan harga, mempromosikan dan mendistribusikan barang dan jasa yang dapat memuaskan kebutuhan pembeli yang ada, dan pemasaran juga mempunyai peran yang sangat penting dalam masyarakat karna pemasaran menyangkut berbagai aspek kehidupan, termasuk bidang ekonomi dan sosial.dan dengan demikian Pondok Pesantren Al-mashduqiah melakukan pemasaran sebelum maupun sesudah terjadinya proses pertukaran demi terciptanya kepuasan baik pembeli maupun penjual.

Pengemasan sebuah produk juga bisa membuat pembeli tertarik untuk membeli produk yang sudah kita jual dan pemberian label atau dekorasi di luar kemasan juga berguna terhadap produk yang akan kita jual, karna dengan adanya dekorasi, label, dan pengemasan yang baik, juga akan membuat para pelanggan tertarik terhadap produk-paroduk yang akan kita promusikan atau yang akan jual tersebut.Maka dengan adanya hal tersebut Pondok Pesantren Al-mahsduqiah memberikan harga yang cukup memuaskan untuk kalangan masyarakat dan juga untuk kalangan para santri yang ada dipondok pesantren tersebut, memodifikasi kemasan produk, merancang promosi khusus, menentukan pilihan saluran distribusi, dan sebagainya.

Berbisnis bukan hanya sekedar berproduksi dan menjual barang kepada konsumen saja. Bisnis perlu namanya trik atau strategi agar kita tidak kalah dengan pesaing lainnya. Apabila kita hanya memasarkan produk bisnis sebatas 
kemampuan kita bisa jadi satu atau dua bulan kita tergeser oleh pesaing lain.Strategi pemasaran produk sangat diperlukan untuk mempercepat penjualan kita. Jika penjualan bisa dijalakan dengan cepat tentu saja perputaran modal juga semakin cepat. Barang yang terlalu banyak di timbun digudang sebenarnya malah menjadi beban perusahaan yang lama-kelamaan akan mengurangi laba dari perusahaan kita. Strategi pemasaran produk yang cepat dan menuju sasaran inilah yang diperlukan agar kita bisa mengelola perusahaan dengan baik. Pemasaran produk merupakan finishing dari produksi barang kita. Bila finishing ini mencapai target tentu saja produksi berikutnya bisa dijalankan lagi.

Strategi pemasaran produk merupakan cara untuk memasarkan produk, dari hasil produksi perusahaan kepada konsumen dengan cepat dan tepat sasaran. Dalam hal ini konsumen menjadi hal utama bagi perusahaan bila pemasaran mencapai target. Dan pemasaran bisa mencapai target apabila produk yang dihasilkan benar-benar menjadi apa yang diinginkan oleh konsumen. Lagi-lagi kepuasan konsumen menjadi hal yang wajib bagi perusahaan. Buat apa perusahaan memproduksi barang sebanyak-banyaknya jika produk tersebut nyatanya tidak disukai konsumen. Untuk mempercepat arus perputaran modal dengan cara penjualan ini.

Saat ini salah satu pesantren di kabupaten Probolinggo telah mengembangkan ekonomi syariah dalam beberapa usaha yang telah diterapkan oleh Pondok Pesantren Al-mahduqiah ini. Dan Pondok Pesantren Al-mahduqiah tidak hanya mengikutsertakan santri dan alumni saja, tetapi juga mengikutsertakan dari kalangan masyarakat sekitarnya. Sebagian di antaranya telah ikut serta menggerakkan roda ekonomi yang berorientasi untuk kemaslahatan masyarakat dan santri. Seperti yang dilakukan oleh Pondok Pesantren Al-Mashduqiah di Kelurahan Patokan Kecamatan Kraksaan Kabupaten Probolinggo. Dimana pesantren tersebut memulai usahanya hanya untuk memenuhi kebutuhan pangan para santrinya untuk dikonsumsi sehari-hari.

Sehingga salah satu Pengasuh Pondok Pesantren Al-Mashduqiah yakni Nyai Hj. Zulfa Badri berinisiatif untuk mendirikan beberapa usaha mengingat kondisi kebutuhan pangan santrinya yang banyak pada saat itu.Lalu berdirilah sebuah home industri Izzi Bakery dengan menjalin kerjasama dengan beberapa para alumni dan juga tokoh masyarakat sekitarnya.

Tetapi tidak berhenti di situ saja lambat laun Pondok Pesantren Almahduqiah mengembangkan usahanya dalam berbagai bidang, seperti home industri Tahu, Tempe dan juga Izzi water. Kini secara tidak langsung Pondok Pesantren telah membuka lapangan pekerjaan untuk masyarakat sekitarnya. Karena itu, berdasarkan uraian dimaksud, maka sangat menarik untuk didiskusikan dan diangkat dalam tulisan ini dengan judul; Pemasaran Produk Bakery Roti di Pondok Pesantren Al-mashduqiah. Patokan Kraksaan Probolinggo. 


\section{Metode Penelitian}

1. Pendekatan dan Jenis Penelitian

Pendekatan penelitian yang dilakukan adalah pendekatan sosiologis dengan melakukan interaksi lingkungan sesuai dengan unit sosial, individu, kelompok, lembaga atau masyarkat.

a. Pendekatan

Dalam penelitian ini menggunakan jenis dan pendekatan kualitatif. Menurut Meleong penelitian kualitatif adalah penelitian yang bermaksud untuk memahami tentang apa yang dialami oeleh subjek penelitian. ${ }^{1}$ Menurut Sugiyono penelitian kualitatif adalah metode penelitian yang berlandasakan pada filsafat postpisitivisme, digunakan untuk meneliti pada kondisi obyek alamiah dimana peneliti adalah sebagai instrument kunci, teknik pengumpulan data dilakukan secara gabungan, analisis data besifat induktif/kualitatif, dan hasil penelitian kualitatif lebih menekankan makna dari pada generalisasinya. ${ }^{2}$

Berdasarkan beberapa pendapat di atas, adapun yang menjadi obyek atau sumber diperolehnya data atau keterangan ysng dapat memperkuat keakuratan penelitian ini adalah Manajemen pemasaran Produk Bakery Roti di Pondok Pesantren Al-mashduqiah, Patokan, Kraksaan, Prorbolinggo.

1. Kehadiran Peneliti

Sesuai dengan jenis penelitian, yaitu penelitian deskriptif maka kehadiran peneliti sangatlah dibutuhkan sebagai instrumen utama, dalam hal ini peneliti harus bertindak sebagai perencana, pemberi tindakan, pengumpul data, penganalisis data, dan juga sebagai pelopor hasil penelitian. Di lokasi peneliti juga sebagai pengamat penuh. Di samping itu kehadiran peneliti sangatlah mutlak keberadaannya karena peneliti harus berinteraksi dengan lingkungan baik manusia dan non manusia yang ada dalam kancah penelitian., karena peneliti merupakan sumber utama dalam penelitian ini.

2. Lokasi Penelitian

Adapun yang di jadikan tempat penelitian skripsi ini adalah Home indutri Bakery Roti di Pondok Pesantren Al-mashduqiah Patokan, Kraksaan, Probolinggo yang terletak di J1. IR. Juanda No.370 Kp. Arab Patokan, Kraksaan, Probolinggo.

3. Sumber Data

a. Data Primer

Sumber data primer yaitu data yang di peroleh langsung dari sumber data penyidik dengan tujuan tertentu. Dan primer adalah data yang di dapat dari Home Industri Bakery Roti di Pondok Pesantren Al-mashduqiah. Melalui pengamatan wawancara.

b. Data Sekunder

Data sekunder yaitu data yang diperoleh dari buku-buku yang berhubungan dengan penelitian. Dan data sekunder juga lebih menghemat biaya dan waktu.

4. Prosedur Pengumpulan Data

\footnotetext{
${ }^{1}$ Meleong," Pengertian Metode Penelitian, ( 2014 ), 40.

2 Sugiyono," Pengertian Penelitian Kualitatif, ( 2014 ), 40.
} 
Teknik pengumpulan data merupakan langkah yang paling strategis dalam sebuah penelitian, sebab tujuan utama dari penelitian adalah mendapatkan data yang akurat, sehingga tanpa mengetahui teknik pengumpulan data peneliti tidak akan mendapatkan data yang memenuhi standar yang ditetapkan. ${ }^{3}$ Teknik pengumpulan data yang digunakan dalam penelitian ini adalah dengan menggunakan metode wawancara, observasi, dan dokumentasi Untuk mendapatkan data yang valid dan akurat, penulis melakukan:

a. Observasi

Observasi adalah suatu teknik pengamatan langsung pada objek penelitian untuk mendapatkan suatu data yang akurat. Dan observasi juga sebuah pengumpulan data dengan mengadakan pengamatan langsung pada objek yang akan diteliti. Guba dan Lincoln dalam Moleong menyatakan salah satu alasan penggunaan metode observasi dalam penelitian kualitatif adalah memungkinkan melihat dan mengamati sendiri fenomena yang terjadi pada saat penelitian. ${ }^{4}$ kemudian mencatat perilaku dan kejadian sebagaimana yang terjadi pada keadaan sebenarnya.adalah untuk mendapatkan gambaran secara langsung tentang eksistensi Produk Bakery Roti.

b. Wawancara

Wawancara yaitu suatu cara untuk mengumpulakan data dengan mengajukan pertanyaan langsung kepada responden dalam hal ini kepada para pengelola Bakery Roti, dan Wawancara merupakan percakapan dengan maksud tertentu, yang dilakukan oleh dua pihak yaitu pewawancara (interviewer) yang mengajukan pertanyaan dan yang diwawancarai (interviewee) yang memberikan jawaban atas pertanyaan yang telah diberikan (pemerintah setempat guna melengkapi data yang diperlukan. Sebagian besar data di peroleh melalui wawancara yang di gunakan untuk mengetahui sepenuhnya yang akan di teliti.

c. Dokumentasi

Dokumentasi merupakan catatan-catatan peristiwa yang sudah berlaku. Dokumen ini berupa bentuk tulisan, gambar, atau karya-karya monumental dari seseorang. Adapun dokumentasi yang digunakan dalam penelitian disini yakni catatan-catatan kecil dan gambar-gambar yang ditemukan peneliti dilapangan.

Dalam penelitian ini dokumentasi diperoleh dari manager Home industri, dan juga pengelola Home Industri itu sendiri yang berupa data, foto, laporan kegiatan, atau segala bentuk dokumentasi yang merekam aktivitas di Home Industri Bakery Roti di Pondok Pesantren Al-mashduqiah Patokan Kraksan Probolinggo.

\section{Analisis Data}

Dalam penelitian ini penulis akan menggunakan metode deskriptif analisis, dengan pertimbangan adanya kesediaan dari pemilik Home Industri untuk menganalisis kondisi Home Industri tersebut. Dan anlisisa data tersebut menggunakan atau melukiskan secara sistematis.

Analisis data yang digunakan dalam penelitian ini adalah analisis interaktif, model ini ada 4 komponen analisis yaitu: pengumpulan data, reduksi

\footnotetext{
${ }^{3}$ Sugiyono," Pengertian Penelitian Kualitatif, ( 2016 ), 224

${ }^{4}$ Meleong," Pengertian Metode Penelitian, ( 2014 ), 174.
} 
data, danpenarikan kesimpulan. Analisis data adalah proses mengorganisasikan dan mengurutkan data kedalam pola, kategori dan satuan uraian dasar sehingga dapat ditemukan tema dan tempat dirumuskan hipotesis kerja seperti yang disarankan oleh data ${ }^{5}$. Langkah-langkah analisis data. ${ }^{6}$

a. Pengumpulan data, yaitu mengumpulkan data dilokasi dipenelitian dangan melakukan obserasi, wawancara, dan dokumentasi dengan menentukan strategi pengumpulan data yang dipandang tepat dan untuk menentukan fokus serta pendalaman data pada proses pengumpulan data berikutnya/

b. Reduksi data, yaitu sebagian proses seleksi, pemfokusan, pengabstrakan, transformasi data kasar yang ada di lapangan langsung dan diteruskan pada pengumpulan data dengan demikian reduksi data dimulai sejak penelitian memfokuskan wilayah penelitian.

c. Penyajian data yaitu rangkaian organisasi informasi yang memungkinkan penelitian dilakukan. Penyajian data diperoleh sebagai jenis, jaringan kerja, keterkaitan kegiatan atau table.

d. Penarikan kesimpulan, yaitu dapat pengumpulan data, penelitian harus mengerti dan tanggap terhadap seseatu yang diteliti langsung dilapangan dengan menyusun pola-pola pengarahan dan sebab akibat.

6. Pengecekan Keabsahan Temuan

Pada penelitian kualitatif peneliti harus mampu mengungkap kebenaran yang objektif, karena itu keabsahan data dalam penelitian kualitatif sangat penting. Hal tersebut bertujuan untuk mengukur tingkat kepercayaan (kredibilitas), Ketergantungan (Dependability), Kepastian (confermability)penelitian kualitatif sehingga dapat dipertanggunjawabkan secara ilmiah. Pengukuran keabsahan data pada penelitian ini dilakukan dengan triangulasi. Menerut Moleong keempat kriteria tersebut adalah:

a. Derajat kepercayaan (Credibility) yang di maksudkan apa yang berhasil di kumpulkan sesuai apa yang ada dalam kenyataan yang sebenarnya terjadi .

b. Ketergantungan (Dependebility) kriteria ini di gunakan untuk menjaga ke hatihatian, sehingga akan terhindar dari terjadinya kesalahan dalam proses pengumpulan data.

c. Kepastian (confermability) kriteria ini di gunakan untuk menilai hasil penelitian yang di lakukan dengan cara mengecek informasi serta interprtasi peneliti.

Sugiyono mengatakan bahwa triangulasi adalah teknik pengumpulan data yang bersifat menggabungkan dari berbagai teknik pengumpulan data dan sumber data yang telah ada.

Uji keabsahan data pada penelitian kualitatif dengan menggunakan triangulasi akan lebih meningkatkan kekuatan data apabila dibandingkan dengansatu pendekatan. Dalam penelitian ini, peneliti menggunakan teknik keabsahan data dengan triangulasi teknik. Triangulasi teknik yaitu peneliti menggunakan teknik pengumpulan data yang berbeda-beda untuk mendapatkan

\footnotetext{
5 Meleong LJ Metodologi Penelitian Kualitatif 2004 hal 208-281, Bandung, Remaja Roesdakrya.

${ }^{6}$ Miles dan huberman Analisis data kualitatif Buku sumber tentang metode-metode bar hal 15-19, Jakarta:UIP
} 
data dari sumber yang sama. Teknik pengumpulan data yang dimaksud berupa wawancara,observasi, dan dokumentasi untuk sumber data yang sama secara serentak Penggunaan triangulasi teknik tersebut dilakukan agar data yang diperoleh dari informan penelitian yang menjadi sumber data primer menjadi lebih valid, konsist, tuntas, dan pasti sehingga dapat dianalisis dan ditarik kesimpulan terkait dengan pemanfaatan Perpustakaan Asmaina terhadap minat baca anak pada jenjang pendidikan dasar dan menengah.

\section{Pembahasan Hasil Penelitian}

Home Industri ini berdiri sebagai upaya untuk meningkatkan perekonomian pondok pesantren Al-mashduqiah. Dan juga sebagai contoh terhadap seluruh masyarakat khusunya bagi santriwan dan santriwati, bahwa di dalam pondok bukan hanya bisa mempelajari tentang ilmu agama ataupun kitab kuning dan yang lainnya, akan tetapi pondok pesantren Al-mashduqiah membuktikan bahwa di dalamnya juga bisa memberikan ilmu tentang bagaimana caranya untuk berwirausaha dan juga bisa mangajarkan tentang kemandirian. Dan jenis roti yang diproduksi oleh Izzi Bakery termasuk dalam kategori roti sobek manis. Saat ini jenis roti yang diproduksi oleh Izzi Bakery ada berbagai bentuk, ukuran, dan rasa yang berbeda. Disamping jenis roti yang diproduksi oleh Izzi Bakery semakin beragam, maka saat ini Izzi Bakery juga telah memiliki beberapa agen atau sales untuk memasarkan produknya. Selain itu, berbeda dengan saat awal berdirinya Izzi Bakery yang masih menggunakan peralatan sederhana dan tradisional, maka saat ini untuk menunjang proses produksinya, Izzi Bakery telah menggunakan beberapa peralatan modern yang cara kerjanya tidak menggunakan tenaga manusia, misalnya mesin mixer untuk mengaduk adonan, serta oven yang memiliki kapasitas besar.

Upaya untuk meningkatkan strategi pemasaran Produk Bakery Roti Pondok Pesantren Al-mashduqiah kini telah melakukan pengembangan produk seperti pengorganisasian, memberikan pelayanan yang baik terhadap konsumen karna dengan adanya sebuah pengembangan tersebut perusahaan akan lebih mudah dalam mencapai kebehasilan dan penjualan produk Bakery Roti, dan untuk meningkatkan perkembangan produk Bakery Bakery Roti tersebut perusahaan harus melakukan yang namanya Promusi, kerja sama, pemasaran secara langsung, memberikan harga yang relatif lebih murah dari toko-toko yang ada di sekitar perusahaan, mengenali para pesaing yang ada di dalam pasar, menciptakan merk yang mudah untuk di ingat/di kenali oleh para konsumen.

\section{Hasil Pencapaian Pemasaran Produk Bakery Roti Pondok Pesantren Al- mashduqiah.}

Stretegi pemasaran yang dilakukan oleh Home Industri Produk Bakery Roti Pondok Pesantren Al-mashduqiah dapat dilihat dalam bagan sebagai berikut. 


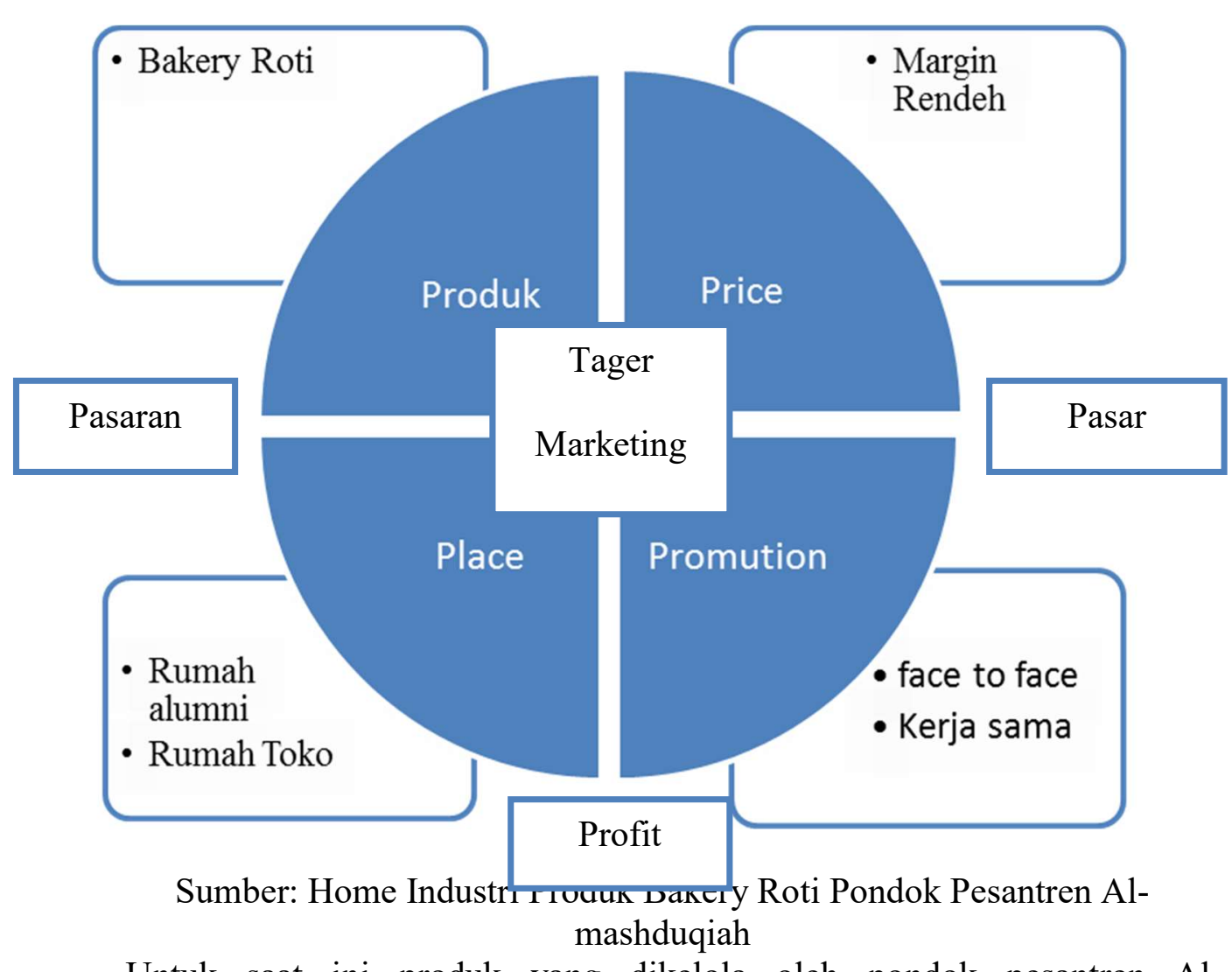

Untuk saat ini produk yang dikelola oleh pondok pesantren Almashduqiah bukan hanya Home Industri Bakery Roti namun didalamnya juga ada beberapa produk yaitu; Tempe, Tahu, dan juga Izzi Water, namun disini yang akan dijelaskan bahwa produk yang dimaksud di atas adalah produk Bakery Roti, untuk saat ini salah satu Pondok Pesantren Al-mashduqiah juga telah mengembangkan Produk Bakery Roti yang begitu lezat dan juga higienis.

Harga yang di tetapkan oleh pondok Pesantren Al-mashduqiah sangatlah rendah karna pondok Pesantren ingin memberikan harga yang relatif murah untuk kalangan santri dan juga masyarakat sekitar, itulah mengapa pondok Pesantren memberikan margin di bawah rata-rata.

Pemasaran yang dilakukan oleh Pondok Pesantren yaitu hanya melalui alumni saja saat ini, karna Pondok Pesantren masih tidak berani untuk membuat toko sendiri dengan adanya persaingan yang begitu ketat, dan begitu pula juga dengan pangsa pasar yang begitu menantang, dan sudah jelas bahwa target untuk pemasaran Produk Bakery Roti saat ini masih rumah alumni saja.

Promusi yang dilakukan oleh Pondok Pesantren Al-mashduqiah adalah dengan cara face to face karna dengan strategi tersebut karyawan bisa mengetahui apa kekurangan yang ada didalamnya dan juga apa yang menjadi keluhan para konsumen selama ini, strategi tersebut relatif cukup gampang untuk dilakukan oleh beberapa orang.

Adapun strategi khusus yang dilakukan oleh marketing Home Industri Produk Bakery Roti Pondok Pesantren Al-mashduqiah dalam memasarkan produknya kepada konsumen ataupun calon konsumen yang baru yaitu; pertama dengan cara strategi face to face, strategi ini terbilang cukup efektif, karna pihak 
Home Industri bisa mendekatkan perusahaannya dengan calon konsumen yang baru dan memberikan kemudahan bagi para konsumen untuk memnuhi kebutuhannya. Tujuan dilakukannya strategi ini agar masyarakat probolinggo lebih mengenal produk dari Home industri Pondok Pesantren karna semakin banyak kalangan masyarakat yang mengetahui dan mengenal produk Home Industri tersebut maka semakin banyak pula keuntungan yang di daparkan oleh Home Industri Bakery Roti Pondok Al-mashduqiah. Kedua strategi dari mulut ke mulut, strategi ini dilakukan dengan cara menawarkan kepada para konsumen yang sudah menjadi pelanggan tetap, karna dengan hal itu juga akan semakin memudahkan pemasaran yang ada di Home Industri Bakery Roti Pondok Pesantren Al-mashduqiah.

walaupun perusahaan menjual produk dengan harga yang murah atau juga bisa disebut dengan harga dibawah rata-rata, Home Industri Bakery Roti sudah mendapatkan laba yang cukup, dan juga sudah bisa menyewa kios untuk penjualan produk yang ada diluar pondok Pesantren Al-mashduqiah. Sesuai dengan pemaparan di atas dengan cara memanfaatkan para alumni Pondok Pesantren Al-mashduqiah kini pemasaran dan juga pendapatkan yang diperoleh semakin meningkatkan dari bulan ke bulan.

\section{Faktor Pendukung dan Penghambat dalam Pemasaran Produk Bakery Roti Pondok Pesantren Al-mashduqiah Patokan Kraksaan Probolinggo}

Dalam suatu instansi, pasti ada faktor pendukung dan faktor penghambat yang dialami, baik kecil maupun besar. Hal ini bisa diselesaikan dengan manajemen yang ada diperusahaan tersebut.

Faktor pendukung dari pemasaran Home Industri Produk Bakery Roti berupa keunggulan produk dari pemasaran Home Industri Produk Bakery Roti berupa keunggulan produk, yang mana produk Bakery Roti memiliki keunggulan yang kompetitif seperti cara pembuatannya yang sangat higienis, dan tidak menggunakan bahan-bahan kimia, yang digunakan hanyalah bahan-bahan alami, itulah mengapa konsumen luar, santri dan juga masyarakat sekitar menyukai produk-produk yang ada di Home Industri Bakery Roti Pondok Pesantren Almashuqiah. Dan Home Industri Produk Bakery Roti juga memberikan harga yang lebih murah dari tempat-tampat yang lainnya, dan keunggulan dari Home Industri Produk Bakey Roti kini di sana juga memberikan program pelatihan untuk masyarakat sekitar dan juga untuk orang-orang dari luar.

Keunggulan Produk dilihat dari sisi produk Bakery Roti memiliki keunggulan yang kompetitif seperti cara pembuatannya yang sangat higienis, dan tidak menggunakan bahan-bahan kimia, yang digunakan hanyalah bahan-bahan alami, itulah mengapa konsumen luar, santri dan juga masyarakat sekitar menyukai produk-produk yang ada di Home Industri Bakery Roti Pondok Pesantren Al-mashuqiah.

Peningkatan produktivitas dilakukan dengan perbaikan tingkat pendidikan dan keahlian mengelola sebuah usaha dan untuk mencapai kesuksesan dalam berbisnis fasilitas sangatlah berpengaruh dalam upaya meningkatkan daya tarik para konsumen dalam bersaing. 
Marketing Mix adalah salah satu dari strategi pemasaran, dimana ada empat kebijaksanaan pokok yang dapat disebut 4P yaitu; Product, Price, Place dan Promotion, dan dari kebijaksanaa tersebut mempunyai fungsi sendiri-sendiri. Strategi pemasaran produk yang dilakukan oleh Home Industri Bakery Roti Pondok Pesantren Al-mashduqiah dalam upaya menarik minat konsumen adalah dengan cara melakukan pemasaran melalui para alumni yang mempromusikannya, memberikan pelayanan yang baik, memberikan kemasan dan bentuk yang unik, memberikan harga yang relatif murah,memberikan rasa dan tekstur yang tidak kalah dengan produk-produk roti lainnya, serta dengan begitu Home Industri Produk Bakery Roti dapat memenuhi keinginan dan kebutuhan para konsumen. Hal ini sesuai dengan hasil wawancara yang diungkapkan oleh Moh Yasin.

Adapun faktor penghambat yang dihadapi Home Industri Produk Bakery Roti Pondok Pesantren Al-mashduqiah kurangnya pengetahuan masyarakat pada umumnya kurang mengetahui tentang adanya Produk Bakery Roti yang tanpa campuran bahan kimia tersebut, dikarenakan minimnya penjualan di luar pondok pesantren Al-mashduqiah. Karna untuk saat ini penjualan Home Industri Produk Bakery Roti Pondok Pesantren Al-mashduqiah hanya melalui para alumni saja, itulah mengapa masyarakat masih minim yang mengenal produk tersebut.

Kurangnya sumber daya manusia juga memicu penjualan dan juga pendapatan yang ada di Home Industri Bakery Roti Pondok Pesantren Almashduqiah karna tanpa adanya karyawan yang kompeten tidak akan berkembang suatu perusahaan, akan tetapi jika untuk karyawan khusus pengantar Produk Bakery Roti seperti sales, disini Home Industri Bakery Roti Pondok Pesantren Almashduqiah masih tidak mempunyai karyawan khusus karna menurut manager Home Industri Produk Bakery Roti masih tidak membutuhkannya, karna penjualan untuk keluar pondok Home Industri disini masih melalui para alumni saja. Dengan kendala seperti itu menjadi tanggungan sekaligus tantangan tersendiri bagi karyawan untuk memasarkan produk yang ada di Home Industri Bakery Roti agar masyarakat lebih mengetahui tentang adanya produk yang tanpa campuran bahan kimia.

Adapun untuk meminimalisir hambatan-hambatan tersebut yaitu mengenalkan Produk Bakery Roti kepada masyarakat dengan cara Mempromusikan produk dengan cara pembuatan bener di luar Pondok Pesantren atau juga dengan cara Promusi periklanan diluar Pondok Pesantren, karna dengan cara seperti itu kalangan masyarakat akan lebih mengenal Produk yang akan kita pasarkan. 


\section{Kesimpulan}

Berdasarkan hasil penelitian dan pembahasan yang telah diuraikan, maka dapat di ambil kesimpulan sebagai berikut:

1. Pencapaian yang telah dihasilkan oleh Home Industri Produk Bakery Roti menarik konsumen yang baru ataupun konsumen lama menjadikan konsumen tetap dengan cara:

a. Strategi promusi merupakan langkah yang harus dilakukan dalam aktivitas manajemen pemasaran dalam strategi promusi ini merupakan langkah pemasaran di bidang pemasaran berupa komunikasi.

b. Melakukan kerjasama dengan beberapa toko mengenai ketersediaan tempat tersebut dan juga menawarkan kerjasama tokoh masyarakat sekitar.

c. melakukan penjualan dan pemasaran langsung diluar pondok yaitu cara menyebarkan produk melalui alumni Pondok Pesantren Al-mashduqiah.

d. menetapkan harga yang ditawarkan dibandingkan dengan produk-produk yang lainnya.

2. Faktor pendukung Home Industri Produk Bakery Roti Pondok Pesantren Almashduqiah dalam memasarkan produk Bakery Roti. Dalam menghadapi persaingan antar sesama penjual produk roti, Home Industri Produk Bakery Roti Pondok Pesantren Al-mashduqiah mempunyai faktor pendukung yaitu:

a. Adanya faktor keunggulan produk

b. Keunggulan harga

c. Produktifitas dan inovasi

\section{Saran} berikut:

Berdasarkan pembahasan diatas, maka ada beberapa saran sebagaimana

1. Bagi Home Industri Produk Bakery Roti

a. Mempertahankan kualitas produk khususnya produk Bakery Roti, sehingga produk tersebut lebih diminati oleh masyarakat dan juga para santri.

b. Home Industri harus lebih memperhatikan tingkat pemasaran, agar penjualannya lebih terarah lagi.

2. Bagi Karyawan

a. Semakin aktif dalam bidang pemasaran produk Bakery Roti agar lebih banyak masyarakat yang mengenalnya.

b. Lebih lincah lagi dalam pembuatan produk Bakery Roti agar lebih banyak lagi produk yang harus di pasarkan. 


\section{DAFTAR PUSTAKA}

Novianto, Aan. Analisis Strategi Pengembangan Bisnis, Bandar Lampung: 2017.

Arlina, Nurbaiti, Lubis. Strategi Pemasaran Dalam Persaingan Bisnis Sumatra Utara: 2004.

Swasta, Basu. Manajemen Pemasaran Modern Yokyakarta. Semanggi Surakarta: 1990.

Latif, Cahya, Fitrih. Strategi Pemasaran Nice Bakery. Tondano: 2013.

Miles, Huberman. Analisis data kualitatif Buku sumber tentang metodemetode. hal 15-19, Jakarta: UIP.

Z, Irsad. Analisis Marketing Mix Produk Price Promotion dan Place yang Memepengaruhi Kepuasan Pelanggan. Jakarta: 2010.

Lj, Meleong. Metodologi Penelitian Kualitatif, Bandung: Remaja Roesdakrya, 2004 hal 208-281.

Khairuman, M. Manajemen pemasaran Produk dan pengembangan produk. Surakarta.

Meleong, Pengertian Metode Penelitian, (2014), 40.

Rianti, M. Pengertian Pemasaran, 2015.

Assauri, Sofjan. Manajemen Pemasaran, Jakarta: PT Raja Grafindo Persada 2017-2018.

Sugiyono. Pengertian Penelitian Kualitatif, ( 2014 ), 40.

Gunara, Thorik. Strategi Andaldan Jitu Praktik Bisnis Muhammad saw, Bandung: 2007.

Yuliana. Peranan Pengembangan Produk Dalam Meningkatkan Volume Penjualan Semarang, Universitas Negeri Islam Walisongo: 2015.

Safitrih, Yola. Strategi Pemasaran, Padang: 2016. 